\title{
Metabolism of Steroid and Amino Acid Moieties of Conjugated Bile Acids in Man
}

\author{
III. CHOLYLTAURINE (TAUROCHOLIC ACID)
}

\author{
Gershon W. Hepner, John A. Sturman, Alan F. Hofmann, and \\ Paul J. Thomas \\ From the Gastroenterology Unit, Mayo Clinic and Mayo Foundation, \\ Rochester, Minnesota 55901, and the Department of Pediatric Research, \\ Institute for Basic Research in Mental Retardation, \\ Staten Island, New York 10314
}

A в S T R A C T After oral administration of $\left[2,4-^{8} \mathrm{H}\right]-$ cholyl[ $\left.{ }^{35} \mathrm{~S}\right]$ taurine to eight healthy subjects with indwelling nasoduodenal tubes, the specific activity of the cholyl and taurine moieties and the distribution of radioactivity in biliary bile acid and urinary metabolites, as well as total urinary and fecal ${ }^{35} \mathrm{~S}$ and ${ }^{3} \mathrm{H}$, were measured at intervals for 4-8 days. Similar measurements were made after $\left[{ }^{35} \mathrm{~S}\right]$ taurine was given orally or intravenously or instilled into the distal intestine. The daily fractional turnover rate of the taurine moiety of cholyltaurine was low and similar to that of the cholyl moiety, indicating that deconjugation occurring during enterohepatic cycling was less than half that previously observed for glycine-conjugated bile acids. Some of the cholyl moiety was absorbed but, since reconjugation occurred predominantly with glycine, little reincorporation into the cholyltaurine pool was observed. Some of the taurine moiety was also absorbed intact but entered large taurine pools, and little reincorporation into the cholyltaurine pool was seen. Oral administration of taurine expanded the cholyltaurine pool and induced a decrease in the fractional turnover rate of the cholyl moiety of cholyltaurine, interpreted to indicate a greater reincorporation of the cholyl moiety because of increased reconjugation with taurine. Taurine moiety not absorbed as taurine appeared to be absorbed largely as sulfate which, like taurine, entered large endogenous pools. Little fecal excretion of ${ }^{\star 5} \mathrm{~S}$ occurred. ${ }^{\infty} \mathrm{S}$ was excreted in urine as taurine and sulfate, and excretion in the first $24 \mathrm{~h}$ (as per-

Dr. Hepner's present address is Department of Medicine, Hershey Medical Center, Pennsylvania State University, Hershey, $\mathrm{Pa} .17033$.

Received for publication 6 April 1972 and in revised form 15 September 1972. centage of administered dose) correlated highly ( $r=$ 0.93) with the daily fractional turnover rate of the taurine moiety. When taurine was instilled into the distal intestine, it appeared as such in plasma, but the more distal the site of instillation, the greater the fraction of urinary ${ }^{35} \mathrm{~S}$ present as sulfate. The $\left[{ }^{35} \mathrm{~S}\right]$ sulfate appeared to have come from bacterial degradation of $\left[{ }^{35} \mathrm{~S}\right]$ taurine because, when $\left[{ }^{35} \mathrm{~S}\right]$ taurine was given intravenously, ${ }^{25} \mathrm{~S}$ was excreted in urine chiefly as $\left[{ }^{*} \mathrm{~S}\right]$ taurine with little $\mathrm{SO}_{4}=-\left[{ }^{\infty} \mathrm{S}\right]$ being present.

\section{INTRODUCTION}

We have previously defined the metabolism of the steroid and amino acid moieties of glycine-conjugated bile acids $(1,2)$ in man. About $18 \%$ of the pool of glycineconjugated bile acids is deconjugated in each enterohepatic cycle and about two-thirds of the steroid moiety liberated is conserved and reconjugated, predominantly with glycine in the liver. Consequently, the synthesis of bile acid glycine is about three times that of the steroid moiety. The glycine liberated from cholyl $\left[1-{ }^{14} \mathrm{C}\right]$ glycine in the gastrointestinal tract is either converted to ${ }^{14} \mathrm{CO}_{2}$ in the intestinal lumen or, if absorbed, enters the large body pool of glycine; virtually none of the glycine liberated in the intestinal lumen can be detected in the glycine used for conjugation with free bile acids in the liver.

In man, about one-quarter of the biliary bile acids are conjugated with taurine (3). Garbutt, Wilkins, Lack, and Tyor (4) administered $\left[24-{ }^{14} \mathrm{C}\right]$ cholyltaurine and calculated its half-life as well as its rate of 7-dehydroxylation after bacterial deconjugation, but they gave no information on the taurine moiety. In this paper we 
describe the synthesis of $\left[2,4-{ }^{3} \mathrm{H}\right]$ cholyl $\left[{ }^{35} \mathrm{~S}\right]$ taurine and its administration to eight healthy subjects in order to characterize simultaneously the metabolism of the cholyl and taurine moieties of the bile acid. In addition, we carried out limited experiments on the metabolism of $\left[{ }^{35} \mathrm{~S}\right]$ taurine in order to interpret our results.

\section{METHODS}

The metabolism of cholyltaurine was studied in eight subjects who were ingesting a normal diet and in two subjects whose taurine intakes were varied. In three additional subjects, $\left[{ }^{35} \mathrm{~S}\right]$ taurine was given orally (two subjects) or intravenously (one subject). In three subjects, $\left[{ }^{35} \mathrm{~S}\right]$ taurine was instilled via a tube placed in the distal ileum or the cecum.

Materials. $\left[2,4-{ }^{3} \mathrm{H}\right]$ cholic acid was prepared from methyl 3 -keto- $7 \alpha, 12 \alpha$-dihydroxy-5 $\beta$-cholanoate (5) and conjugated with taurine (6). The final specific activity was approximately $\left.1 \mathrm{mCi} / \mathrm{mmol} .{ }^{35} \mathrm{~S}\right]$ taurine (Amersham/Searle Corp., Arlington Heights, Ill.) was conjugated with cholic acid to yield cholyl $\left.{ }^{35} \mathrm{~S}\right]$ taurine of specific activity approximately $1 \mathrm{mCi} / \mathrm{mmol}$. Radiopurity of both compounds was greater than $95 \%$, as shown by zonal scanning (7) of a sample chromatographed on a silicic acid plate with $n$ butanol: acetic acid: water $(80: 10: 10, \mathrm{vol} / \mathrm{vol} / \mathrm{vol})$ as solvent for the ${ }^{35} \mathrm{~S}$ compound ( $R_{f}$ : taurine, 0.29 ; cholyltaurine, $0.41)$ and isoamyl acetate: propionic acid:propanol: water (4:3:2:1, vol/vol/vol/vol) for the ${ }^{3} \mathrm{H}$ compound $\left(R_{f}\right.$ : cholyltaurine, 0.11 ; cholic acid, 1.0).

Metabolism of cholyltaurine. Eight healthy fasting subjects were given $10-20 \mu \mathrm{Ci}$ of $\left[2,4-{ }^{3} \mathrm{H}\right]$ cholyltaurine and $10-20 \mu \mathrm{Ci}$ of cholyl[ $\left.{ }^{35} \mathrm{~S}\right]$ taurine in a milk shake. The radiation exposure in 1 mo from $20 \mu \mathrm{Ci}$ of cholyl[ $\left.{ }^{35} \mathrm{~S}\right]$ taurine is calculated as about equal to that received from natural and cosmic sources; all subjects gave informed consent. On the morning on which the study commenced, a nasoduodenal tube was passed. Its tip was positioned, with the aid of fluoroscopy, at the duodenal-jejunal flexure where it remained throughout the study. During the study, the subjects carried out their usual activities and were instructed to eat three meals per day. Samples of duodenal bile were taken over a period of 4 days; $2 \mathrm{ml}$ of bile was removed after the intravenous administration of $75 \mathrm{U}$ of cholecystokinin (Cecekin AB Vitrum, Stockholm, Sweden). The samples were collected in $20 \mathrm{ml}$ of ethanol, heated to precipitate protein, filtered, and then dried. The residue was dissolved in $0.5-1.0 \mathrm{ml}$ of methanol and stored at $4^{\circ} \mathrm{C}$.

A sample of bile was chromatographed on a $20-\times 20-\mathrm{cm}$ silicic acid plate with isoamyl acetate:propionic acid:npropanol: water $(40: 30: 20: 10, \mathrm{vol} / \mathrm{vol} / \mathrm{vol} / \mathrm{vol})$ or $n$-butanol: acetic acid: water $(80: 10: 10, \mathrm{vol} / \mathrm{vol} / \mathrm{vol})$ as solvent; cholyltaurine standards were run on either side of the bile sample. The region of the plate containing cholyltaurine was scraped off and eluted with $0.6 \mathrm{ml}$ of $0.05 \mathrm{~N}$ $\mathrm{NaOH}$. Part of the eluate was analyzed for bile acid mass by the hydroxysteroid dehydrogenase method (8) and part was counted for ${ }^{8} \mathrm{H}$ and ${ }^{35} \mathrm{~S}$ to yield the specific activity of the two moieties of cholyltaurine. Samples were run in duplicate, and the coefficient of variation was $8 \%$.

A second sample of bile was analyzed by zonal scanning to determine the distribution of radioactivity among individual bile acid conjugates. The separation was performed on silicic acid plates with isoamyl acetate: propionic acid: propanol: water $(40: 30: 20: 10, \mathrm{vol} / \mathrm{vol} / \mathrm{vol} / \mathrm{vol})$. Radioactivity $\left({ }^{3} \mathrm{H}\right.$ and ${ }^{35} \mathrm{~S}$ ) present in each $4 \mathrm{~mm}$ section was calculated as percentage of total radioactivity recovered.
Reference compounds were chromatographed simultaneously and radioactivity was assigned to $(a)$ cholyltaurine, (b) deoxycholyl- or chenodeoxycholyltaurine, (c) cholylglycine, and $(d)$ deoxycholylglycine.

Bile acid kinetics were calculated according to a firstorder kinetic model (9). The equation for the specific activity decay curve of $\left[2,4-^{8} \mathrm{H}\right]$ cholyltaurine and cholyl$\left[{ }^{35} \mathrm{~S}\right]$ taurine was calculated by least-squares; the linearity of the logarithmic specific activity decay was indicated by a correlation coefficient of greater than 0.97 for all studies. $\left[2,4-{ }^{3} \mathrm{H}\right]$ cholyltaurine specific activity at time 0 was obtained by extrapolation and the dose of radioactivity administered was divided by this value to give the pool size. The slope of the logarithmic specific activity decay curve is the rate constant or fractional turnover $\left(\right.$ days $\left.^{-1}\right)$. The daily synthesis of the cholyl and taurine moieties of cholyltaurine was obtained by multiplying the pool (millimoles) by the daily fractional turnover.

Two 4-day stool samples were collected from each subject. After homogenization, a $1 \mathrm{~g}$ sample was dried and combusted in oxygen to convert ${ }^{3} \mathrm{H}$ radioactivity to $\left[{ }^{3} \mathrm{H}\right]$ $\mathrm{H}_{2} \mathrm{O}$ (Packard oxidizer, model 305, Packard Instrument Co., Inc., Downers Grove, Ill.). A second $1 \mathrm{~g}$ sample was mixed with $2 \mathrm{ml}$ of $70 \%$ perchloric acid- $10 \mathrm{~N}$ sulfuric acid $(1: 10 \mathrm{vol} / \mathrm{vol})$ and heated in a liquid scintillation vial on a hot plate at low heat until the solution was colorless and all solid matter was digested (this required at least $48 \mathrm{~h}$ ). 1-2 $\mathrm{ml}$ of water was then added and heating was continued until the water had evaporated, thereby removing ${ }^{3} \mathrm{H}$ as $\left[{ }^{3} \mathrm{H}\right] \mathrm{H}_{2} \mathrm{O}$ and enabling counting of residual ${ }^{35} \mathrm{~S}$ as $\left[{ }^{35} \mathrm{~S}\right]$ $\mathrm{H}_{2} \mathrm{SO}_{4}$. The sample was counted with $15 \mathrm{ml}$ of Packard "Insta-Gel."

Urine samples were collected daily. ${ }^{3} \mathrm{H}$ in urine water was determined by distilling the urine from a liquid scintillation vial placed in the heated combustion chamber of the Packard oxidizer and counting the $\left[{ }^{3} \mathrm{H}\right] \mathrm{H}_{2} \mathrm{O}$ in the distillate. The residue, which was found to contain only ${ }^{35} \mathrm{~S}$, was then digested with the perchloric-sulfuric acid mixture and counted as described.

Taurine concentration in plasma of two subjects $\left(\mathrm{CT}_{1}\right.$ and $\mathrm{CT}_{2}$ ) and urine of all subjects was determined by using a Beckman 120C automatic amino acid analyzer (Beckman Instruments, Inc., Fullerton, Calif.). Plasma was prepared for analysis by precipitating the protein with an equal volume of $6 \%$ sulfosalicylic acid and centrifugation; urine was prepared for analysis as previously described (10).

$\left[{ }^{35} \mathrm{~S}\right]$ sulfate was determined by counting samples of urine or plasma, as prepared for amino acid analysis, before and after precipitation of sulfate by the addition of excess barium chloride solution (in the presence of added carrier sulfate). In each case, $1 \mathrm{ml}$ of aqueous solution was dissolved in $10 \mathrm{ml}$ of Triton X-100-toluene phosphor (11) and counted for $100 \mathrm{~min}$ in a Packard 3320 liquid scintillation counter.

Radioactivity which remained after sulfate precipitation was assumed to be taurine on the basis of the following observations. Urine and plasma samples (sometimes concentrated as described by Wainer, King, Goodman, and Thomas [12]) analyzed with a flow-cell scintillation counter coupled to an amino acid analyzer (11) showed two peaks corresponding to a frontal elution and to the position of authentic taurine. After precipitation of sulfate with barium chloride, the frontal elution peak almost completely disappeared, the radioactivity remaining in this position representing less than $0.2 \%$ of the total in the sample for all samples analyzed. The area of the taurine peak was un- 
changed by this procedure, confirming that no taurine was precipitated by the $\mathrm{BaCl}_{2}$. The subsequent identification of radioactive taurine was further confirmed by concentration of the sulfate-cleared samples (12) and co-chromatography with authentic taurine in two dimensions on Whatman no. 1 paper, using phenol: water (72:28, vol/vol) containing $0.03 \%$ EDTA as the first solvent and $n$-butanol: propionic acid: water (46:23:31, vol/vol/vol) as the second solvent. After drying, the chromatograms were applied to $x$-ray film (Kodak Blue Brand, Eastman Kodak Co., Rochester, N. Y.) for 5-6 wk to locate radioactivity and then sprayed with ninhydrin $(0.2 \%$ in acetone) to locate the authentic taurine. The ninhydrin-positive spot in each case coincided with the single radioactive compound.

Effect of taurine supplementation on pool size and kinetics of cholyltaurine. Two subjects $\left(\mathrm{CT}_{3}\right.$ and $\mathrm{CT}_{9}$ ) were admitted to a metabolic unit for determination of the effect of taurine feeding on the pool size and fractional turnover of the cholyl moiety of cholyltaurine. One subject $\left(\mathrm{CT}_{8}\right)$ was studied three times at intervals of 4 wk-first on a normal diet, then on a diet supplying $9.0 \mathrm{~g}$ of taurine per day (beginning 7 days before the study and lasting for a total of 12 days), and then on a taurine-free diet. The second subject was studied twice-first on a taurine-free diet and then on a diet supplying $4.5 \mathrm{~g}$ of taurine per day (beginning 7 days before the study and lasting a total of 14 days). Pool size and kinetics were determined by the methods described above. In these subjects, it was possible to identify a ${ }^{35} \mathrm{~S}$ component in urine which was not sulfate or taurine. The bulk of this radioactivity, which composed $<5 \%$ of urinary ${ }^{25} \mathrm{~S}$ radioactivity, chromatographed with authentic isethionic acid, as described by Goodman, Wainer, King, and Thomas (13).

Metabolism of $\left[{ }^{35} S\right]$ taurine. $60 \mu \mathrm{Ci}$ of $\left[{ }^{35} \mathrm{~S}\right]$ taurine was administered intravenously to two subjects ( $T_{1}$ and $T_{2}$ ); a third subject $\left(\mathrm{T}_{3}\right)$ received $12 \mu \mathrm{Ci}$ of $\left[{ }^{35} \mathrm{~S}\right]$ taurine by mouth. All had indwelling nasoduodenal tubes. Duodenal bile was obtained $12 \mathrm{~h}$ after the dose, and the specific activity of the taurine moiety of cholyl $\left[{ }^{35} \mathrm{~S}\right]$ taurine was determined. Cholyltaurine pool size had been determined in a separate experiment in these three subjects by isotope dilution after the administration of $10-20 \mu \mathrm{Ci}$ of $\left[2,4-^{2} \mathrm{H}\right]$ cholyltaurine, and the results could thus be expressed as percentage of the dose of $\left[{ }^{35} \mathrm{~S}\right]$ taurine incorporated into cholyltaurine in $12 \mathrm{~h}$.

Urine was collected from the three subjects after the dose of $\left[{ }^{86} \mathrm{~S}\right]$ taurine, and the percentages of urinary ${ }^{35} \mathrm{~S}$ found in sulfate and taurine were determined. Interval samples of plasma were also obtained for the estimation of plasma taurine specific activity.

Absorption of taurine. Three subjects $\left(\mathrm{T}_{4}, \mathrm{~T}_{5}\right.$, and $\left.\mathrm{T}_{0}\right)$ were given $0.25 \mathrm{mmol}$ of $\left[{ }^{35} \mathrm{~S}\right]$ taurine $(10 \mu \mathrm{Ci})$ by infusion through a nasointestinal tube. The tip of the tube was visualized fluoroscopically $50 \mathrm{~cm}$ from the ileocecal valve in $T_{4}, 20 \mathrm{~cm}$ from the ileocecal valve in $T_{5}$, and within the cecum in $T_{6}$. These subjects had recently undergone a colonic perfusion study so that intestinal bacteria may have been decreased in number. $12 \mathrm{~h}$ after the $\left.{ }^{35} \mathrm{~S}\right]$ taurine was infused, the tube was withdrawn to the duodenum and a sample of bile was obtained after intravenous injection of $75 \mathrm{U}$ of cholecystokinin. The specific activity of the taurine moiety of cholyltaurine was determined. Cholyltaurine pool size had been determined in a separate experiment in all three subjects; in this way the results could be expressed as percentage of the dose of $\left.{ }^{35} \mathrm{~S}\right]$ taurine incorporated into cholyltaurine in $12 \mathrm{~h}$. In addition, urine collections were
TABLE I

Pool Size, Daily Fractional Turnover, and Daily Synthesis in Normal Subjects

\begin{tabular}{|c|c|c|c|c|c|}
\hline \multirow[b]{2}{*}{ Subject } & \multirow{2}{*}{$\begin{array}{c}\text { Cholyl- } \\
\text { taurine } \\
\text { pool }\end{array}$} & \multicolumn{2}{|c|}{$\begin{array}{l}\text { Daily fractional } \\
\text { turnover }\end{array}$} & \multicolumn{2}{|c|}{ Synthesis } \\
\hline & & Cholyl & Taurine & Cholyl & Taurine \\
\hline & mmol & \multicolumn{2}{|c|}{$\%$} & \multicolumn{2}{|c|}{$\mathrm{mmol} / \mathrm{day}$} \\
\hline $\mathrm{CT}_{1}$ & 0.74 & 61 & 65 & 0.45 & 0.48 \\
\hline $\mathrm{CT}_{2}$ & 0.83 & 56 & 51 & 0.46 & 0.42 \\
\hline $\mathrm{CT}_{3}$ & 1.20 & 34 & 32 & 0.41 & 0.38 \\
\hline $\mathrm{CT}_{4}$ & 0.78 & 39 & 27 & 0.30 & 0.21 \\
\hline $\mathrm{CT}_{5}$ & 1.45 & 46 & 38 & 0.67 & 0.55 \\
\hline $\mathrm{CT}_{6}$ & 0.96 & 37 & 42 & 0.36 & 0.40 \\
\hline $\mathrm{CT}_{7}$ & 1.26 & 41 & 35 & 0.52 & 0.44 \\
\hline $\mathrm{CT}_{8}$ & 0.62 & 32 & 32 & 0.20 & 0.20 \\
\hline Mean & 0.98 & 43.2 & 40.3 & 0.42 & 0.39 \\
\hline $\mathrm{SE}$ & 0.10 & 3.7 & 4.4 & 0.05 & 0.04 \\
\hline
\end{tabular}

made for determination of the taurine/sulfate ratio of urinary radioactivity, and plasma samples were collected up to $48 \mathrm{~h}$ after administration of $\left[{ }^{35} \mathrm{~S}\right]$ taurine for determination of plasma taurine specific activity.

\section{RESULTS}

Fractional turnover and synthesis rates of cholyl and taurine moieties of cholyltaurine. The mean daily fractional turnover of the taurine moiety was not significantly different from that of the cholyl moiety (Table I). The daily syntheses of the cholyl and taurine moieties were not significantly different since the daily fractional turnover rates of these moieties were similar.

Distribution of radioactivity in biliary bile acids. There was a progressive decrease of ${ }^{8} \mathrm{H}$ in cholyltaurine and a reciprocal increase of ${ }^{8} \mathrm{H}$ in cholylglycine and

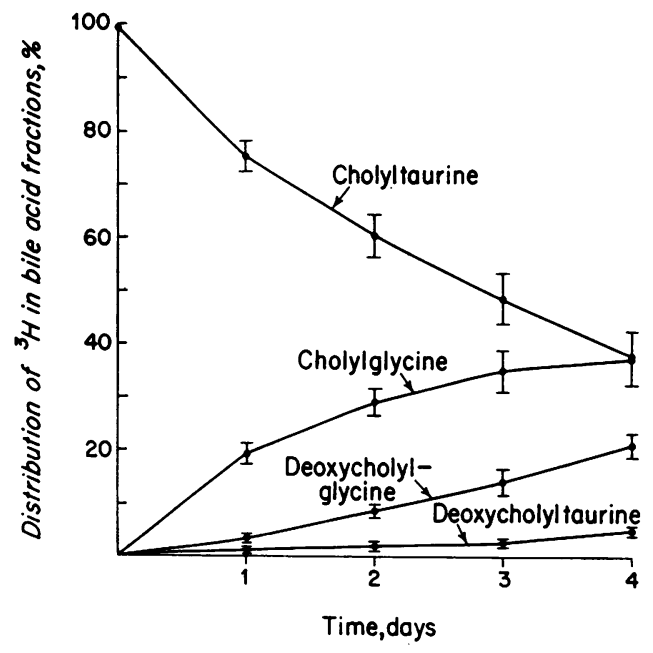

FIgURE 1 Time-course of distribution of ${ }^{3} \mathrm{H}$ among conjugated bile acid classes, shown as means. Classes were separated by thin-layer chromatography. 
TABLE II

Effect of Taurine Supplementation on Pool Size of Cholyltaurine and Kinetics of Cholyl Moiety of Cholyltaurine

\begin{tabular}{|c|c|c|c|c|c|c|}
\hline \multirow[b]{2}{*}{ Subject } & \multicolumn{3}{|c|}{ Cholyltaurine pool } & \multicolumn{3}{|c|}{$\begin{array}{l}\text { Daily fractional turnover } \\
\text { of cholyl moiety of } \\
\text { cholyltaurine }\end{array}$} \\
\hline & $\begin{array}{c}\text { Normal } \\
\text { diet }\end{array}$ & $\begin{array}{c}\text { Low } \\
\text { taurine }\end{array}$ & $\begin{array}{l}\text { Taurine- } \\
\text { supple- } \\
\text { mented }\end{array}$ & $\begin{array}{c}\text { Normal } \\
\text { diet }\end{array}$ & $\begin{array}{c}\text { Low } \\
\text { taurine }\end{array}$ & $\begin{array}{l}\text { Taurine- } \\
\text { supple- } \\
\text { mented }\end{array}$ \\
\hline & & mmol & & & $\%$ & \\
\hline $\mathrm{CT}_{3}$ & 1.20 & 1.14 & 3.09 & 34 & 45 & 29 \\
\hline $\mathrm{CT}_{9}$ & - & 1.07 & 2.20 & - & 54 & 34 \\
\hline
\end{tabular}

deoxycholylglycine, as well as deoxycholyltaurine, during the 4 days of the study (Fig. 1). After 4 days, the mean $( \pm \mathrm{SE})$ percentages of ${ }^{8} \mathrm{H}$ in cholyltaurine and cholylglycine were equal $(37.0 \pm 5.0 \%)$. The distribution of ${ }^{8} \mathrm{H}$ in the biliary bile acids varied considerably among the subjects. In two subjects $\left(\mathrm{CT}_{1}\right.$ and $\left.\mathrm{CT}_{2}\right)$ who had the highest fractional turnover rate of the cholyl moiety, nearly half of the ${ }^{3} \mathrm{H}$ in the biliary bile acids was in cholylglycine after 4 days whereas in subjects $\mathrm{CT}_{4}$ and $\mathrm{CT}_{6}$, only 25 and $21 \%$ of the ${ }^{3} \mathrm{H}$ was in this fraction. ${ }^{35} \mathrm{~S}$ was present exclusively in cholyltaurine throughout the experiment and did not appear in deoxycholyl- or chenodeoxycholyltaurine.

Effect of expansion of cholyltaurine pool on kinctics of cholyltaurine. Since taurine supplementation is known to increase the proportion of bile acids which are conjugated with taurine (14), it should increase the cholyl-

TABLE III

${ }^{35} \mathrm{~S}$ and ${ }^{3} \mathrm{H}$ in Stool in 8 Days and in Urine in 6 Days after Administration of $\left[2,4{ }^{3} \mathrm{H}\right]$ Cholyl $\left[{ }^{35} \mathrm{~S}\right]$ taurine

\begin{tabular}{|c|c|c|c|c|}
\hline \multirow[b]{3}{*}{ Subject } & \multicolumn{4}{|c|}{ Recovery } \\
\hline & \multicolumn{2}{|c|}{${ }^{35} \mathrm{~S}$} & \multicolumn{2}{|c|}{${ }^{3} \mathrm{H}$} \\
\hline & Stool & Urine & Stool & Urine* \\
\hline & \multicolumn{4}{|c|}{$\%$} \\
\hline $\mathrm{C}^{\prime} \mathrm{T}_{1}$ & 8.5 & 52 & 62 & 2.2 \\
\hline $\mathrm{CT}_{2}$ & 5.3 & 52 & 53 & 2.5 \\
\hline $\mathrm{CT}_{3}$ & 5.8 & 63 & 50 & 4.2 \\
\hline $\mathrm{CT}_{4}$ & 7.8 & 41 & 55 & 3.3 \\
\hline $\mathrm{CT}_{5}$ & 4.1 & 26 & 42 & 3.3 \\
\hline $\mathrm{CT}_{6}$ & 7.4 & 43 & 36 & 6.8 \\
\hline $\mathrm{CT}_{i}$ & 14.6 & 40 & 48 & 4.1 \\
\hline $\mathrm{CT}_{8}$ & 9.6 & 30 & 24 & 3.6 \\
\hline Mean & 7.9 & 43 & 46 & 3.8 \\
\hline $\mathrm{SE}$ & 1.2 & 4 & 5 & 0.5 \\
\hline
\end{tabular}

* Radioactivity present entirely as $\left[{ }^{3} \mathrm{H}\right] \mathrm{H}_{2} \mathrm{O}$ based on quantitative recovery in distillate and absence of ${ }^{3} \mathrm{H}$ radioactivity in residue. taurine pool. The appearance of ${ }^{3} \mathrm{H}$ in cholylglycine indicated that, after liberation in the intestinal lumen, the cholyl moiety of cholyltaurine was absorbed and reconjugated predominantly with glycine. Therefore, if the pattern of conjugation could be changed from predominantly glycine to predominantly taurine, any cholyl moiety which was reabsorbed should now be reconjugated predominantly with taurine. Since the decrease of the specific activity of the cholyl moiety of cholyltaurine is caused by loss of the cholyl moiety from the pool, decreased loss into cholylglycine should be associated with a slower fractional turnover rate of the cholyl moiety of cholyltaurine. Table II shows that taurine supplementation caused an expansion of the cholyltaurine pool and a decrease in the fractional turnover rate of the cholyl moiety of cholyltaurine in two subjects.

Fate of ${ }^{35} S .{ }^{35} \mathrm{~S}$ was excreted chiefly in urine in 6 days with little appearing in stool in 8 days (Table III). After 8 days, about half of the administered radioactivity was still present in the body and was being excreted slowly (Fig. 2). ${ }^{35} \mathrm{~S}$ recovered in urine was predominantly in sulfate and taurine (Table IV). In two of the four subjects followed for $2 \mathrm{wk}$, the percentage of urinary radioactivity present as sulfate tended to decrease with time, with a reciprocal increase in the percentage present as taurine. In these subjects, a sizable fraction of liberated taurine appeared to have been absorbed as such after bacterial deconjugation.

When taurine was instilled directly into the intestine, ${ }^{35} \mathrm{~S}$ could be shown to be present in $\left[{ }^{35} \mathrm{~S}\right]$ taurine in plasma in two of three subjects, indicating that taurine can be absorbed from the distal intestinal lumen. Specific activity values were low and less than $1 \%$ of the absorbed taurine appeared in cholyltaurine (Table V).

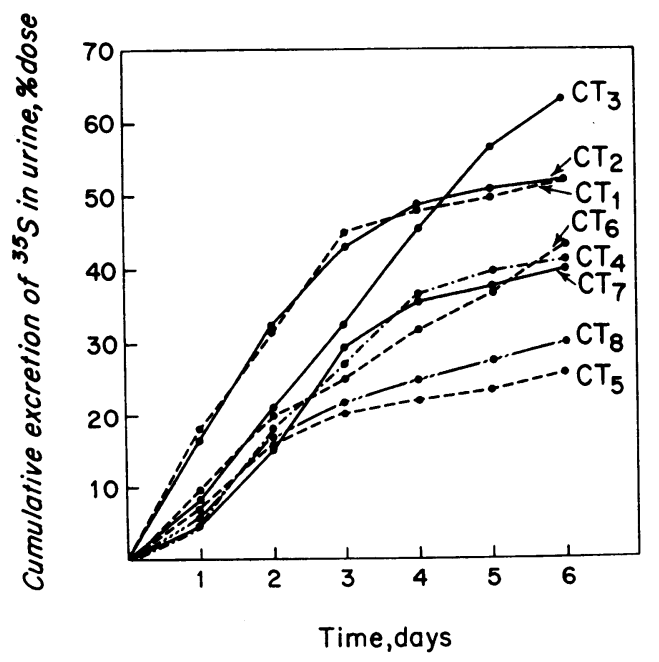

FIgure 2 Cumulative excretion of ${ }^{35} \mathrm{~S}$ in urine after cholyi$\left[{ }^{35} \mathrm{~S}\right]$ taurine. 
TABLE IV

Urinary ${ }^{35} S$ as Sulfate (Percent of Total Urinary ${ }^{35} S$ ) after Oral Administration of Cholyl[ $\left.{ }^{35} S\right]$-taurine*

\begin{tabular}{lccccc}
\hline & \multicolumn{5}{c}{ Dayst } \\
\cline { 2 - 5 } Subjects & $1-3$ & $4-6$ & $7-9$ & $10-12$ & $13-15$ \\
\hline & & & $\%$ & & \\
$\mathrm{CT}_{1}$ & 85 & 70 & & & \\
$\mathrm{CT}_{2}$ & 88 & 73 & & & \\
$\mathrm{C}_{3}$ & 86 & 89 & & & \\
$\mathrm{CT}_{4}$ & 77 & 81 & & & \\
$\mathrm{CT}_{5}$ & 61 & 21 & 22 & 17 & 18 \\
$\mathrm{C}_{5}$ & 82 & 80 & 74 & 76 & 73 \\
$\mathrm{CT}_{7}$ & 82 & 89 & 79 & 62 & 61 \\
$\mathrm{CT}_{8}$ & 71 & 71 & 49 & 36 & 24 \\
\hline
\end{tabular}

* When $\left[{ }^{35} \mathrm{~S}\right]$ taurine was given orally, $34 \%$ of urinary ${ }^{35} \mathrm{~S}$ was present as $\left[{ }^{36} \mathrm{~S}\right]$ sulfate; when given intravenously, $16 \%$, on the average, of urinary ${ }^{35} \mathrm{~S}$ was present as $\left[{ }^{35} \mathrm{~S}\right]$ sulfate.

$\dagger$ Each value is the mean of daily samples collected during the

3 day interval. Remainder of radioactivity was essentially $\left[{ }^{35} \mathrm{~S}\right]$ taurine.

When taurine was given orally, it was well absorbed based on fecal recovery of $\left[{ }^{35} \mathrm{~S}\right]$, but less than $1 \%$ appeared in cholyltaurine. When taurine was given intravenously, again less than $1 \%$ appeared in cholyltaurine.

The percentage of urinary activity found in urinary sulfate after administration of $\left[{ }^{35} \mathrm{~S}\right]$ taurine was influenced by the route by which the $\left[{ }^{35} \mathrm{~S}\right]$ taurine was administered (Table VI). It was lowest when the taurine was administered parenterally and not exposed to intestinal bacteria, higher when the taurine was given orally, still higher when the taurine was exposed to ileal bacteria, and highest when the taurine was exposed to colonic bacteria. The daily fractional turnover rate and the recovery of ${ }^{35} \mathrm{~S}$ in urine in $24 \mathrm{~h}$ (chiefly as sulfate) correlated highly $(r=0.93)$ (Fig. 3).

Fate of ${ }^{3} \mathrm{H}$. ${ }^{3} \mathrm{H}$ was recovered from feces and urine (Table III). Urinary ${ }^{3} \mathrm{H}$ was present entirely as $\left[{ }^{3} \mathrm{H}\right]$ $\mathrm{H}_{2} \mathrm{O}$ since all radioactivity appeared in the distillate, consistent with the view that the cholyl moiety is excreted entirely by the fecal route. The $\left[{ }^{3} \mathrm{H}\right] \mathrm{H}_{2} \mathrm{O}$ is considered to originate from bacterial liberation of ${ }^{3} \mathrm{H}$, presumably by bacterial desaturation (15) and is thus an artifact resulting from the use of a bile acid containing ${ }^{8} \mathrm{H}$ at a position on the steroid ring accessible to bacterial enzymes.

The percentage of administered ${ }^{3} \mathrm{H}$ absorbed from the distal intestine and entering the pool of body water was estimated by multiplying the maximal specific activity of water during the first 6 days after administration of $\left[2,4-^{8} \mathrm{H}\right]$ cholyltaurine by the pool of body water (body weight times 0.6 [16]) and dividing this product by the administered dose. The data were normalized for a
TABLE V

Incorporation of $\left[{ }^{35} S\right]$ taurine Into Cholyltaurine 12 H After Administration*

\begin{tabular}{|c|c|c|c|c|}
\hline \multirow[b]{2}{*}{ Subject } & \multirow[b]{2}{*}{ Route } & \multicolumn{2}{|c|}{ Cholyltaurine } & \multirow{2}{*}{$\begin{array}{c}\left.{ }^{[35} \mathrm{S}\right] \text { taurine } \\
\text { incorporated } \\
\text { into choly- } \\
\text { taurine }\end{array}$} \\
\hline & & Sp act & Pool size & \\
\hline & & $\begin{array}{c}\mu \mathrm{Ci} / \mu \mathrm{mol} \\
\times 10^{6}\end{array}$ & $\mathrm{mmol}$ & $c$ dose \\
\hline$T_{1}$ & i.v. & 36.8 & 1.20 & 0.44 \\
\hline $\mathrm{T}_{2}$ & i.v. & 65.0 & 1.07 & 0.77 \\
\hline $\mathrm{T}_{3}$ & p.o. & 104.6 & 0.66 & 0.69 \\
\hline $\mathrm{T}_{4}$ & Ileumt & 25.5 & 0.74 & 0.29 \\
\hline $\mathrm{T}_{5}$ & Ileum§ & 12.7 & 0.62 & 0.22 \\
\hline $\mathrm{T}_{6}$ & Cecum & 7.3 & 0.80 & 0.09 \\
\hline
\end{tabular}

* All data normalized for $10 \mu \mathrm{Ci}$ dose of $\left[{ }^{35} \mathrm{~S}\right]$ taurine. Actual dose administered: $\mathrm{T}_{1}$ and $\mathrm{T}_{2}, 60 \mu \mathrm{Ci} ; \mathrm{T}_{3}, 12 \mu \mathrm{Ci} ; \mathrm{T}_{4}, \mathrm{~T}_{5}$, and $\mathrm{T}_{6}, 10 \mu \mathrm{Ci}$.

† At $50 \mathrm{~cm}$ proximal to ileocecal valve.

$\S$ At $20 \mathrm{~cm}$ proximal to ileocecal valve.

dose of $10 \mu \mathrm{Ci}$ of ${ }^{3} \mathrm{H}$. The percentage of the dose calculated to have entered the pool of body water (Table VII) was greater than the percentage of administered dose recovered in the urine in 14 days (5.7-14.2\%), presumably reflecting the excretion rate of body water of which only about $2 \%$ is excreted per day in the urine (16).

\section{DISCUSSION}

Deconjugation during enterohepatic cycling. The low rates of incorporation, into cholyltaurine, of intravenously or orally administered taurine suggest that little reincorporation of taurine occurred after deconjugation.

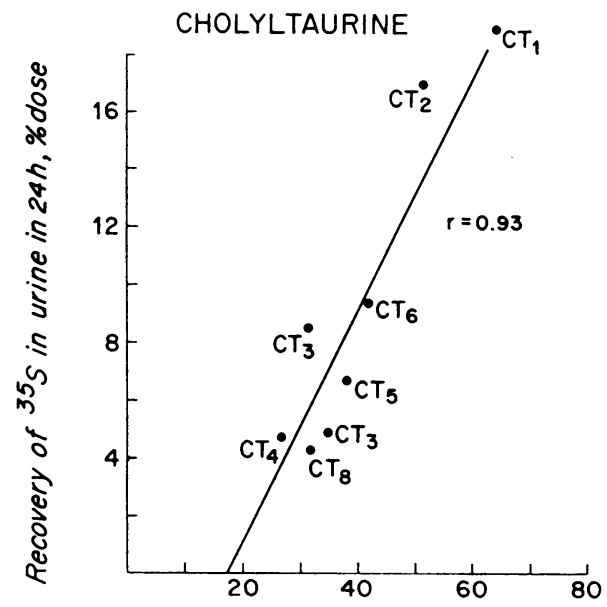

Daily fractional turnover of taurine moiety, $\%$

FIGURE 3 Relationship between daily fractional turnover of taurine moiety of cholyltaurine and $24 \mathrm{~h}$ urinary recovery of ${ }^{35} \mathrm{~S}$ (expressed as percent of dose). 
TABLE VI

Recovery and Chemical Form of Urinary ${ }^{35} S$ after $\left[{ }^{35} S\right]$ taurine: Influence of Route of Administration

\begin{tabular}{|c|c|c|c|c|c|c|c|c|c|c|c|}
\hline \multirow[b]{3}{*}{ Subject } & \multirow[b]{3}{*}{ Route } & \multicolumn{10}{|c|}{ Time (days)* } \\
\hline & & \multicolumn{2}{|c|}{$1-3$} & \multicolumn{2}{|c|}{$4-6$} & \multicolumn{2}{|c|}{$7-9$} & \multicolumn{2}{|c|}{$10-12$} & \multicolumn{2}{|c|}{$13-15$} \\
\hline & & Recovery & $\begin{array}{c}{ }^{35} \mathrm{~S} \\
\text { as } \mathrm{SO}_{4}\end{array}$ & Recovery & $\begin{array}{c}{ }^{85} \mathrm{~S} \\
\text { as } \mathrm{SO}_{4}\end{array}$ & Recovery & $\begin{array}{c}{ }^{36} \mathrm{~S} \\
\text { as } \mathrm{SO}_{4}\end{array}$ & Recovery & $\begin{array}{c}{ }^{25} \mathrm{~S} \\
\text { as } \mathrm{SO}_{4}\end{array}$ & Recovery & $\begin{array}{c}{ }^{35 S} \\
\text { as } \mathrm{SO}_{4}\end{array}$ \\
\hline & & $\%$ dose & $\%$ & $\%$ dose & $\%$ & $\%$ dose & $c_{i}$ & $\%$ dose & $\%$ & $\%$ dose & $\%$ \\
\hline 1 & i.v. & 18 & 10 & 8 & 19 & 4 & 18 & $<1$ & 18 & & \\
\hline 2 & i.v. & 16 & 15 & 3 & 15 & $<1$ & 2.3 & $<1$ & 24 & & \\
\hline 3 & p.o. & 6 & 42 & 15 & 36 & 19 & 35 & 8 & 28 & 3 & 30 \\
\hline 4 & Ileum & 29 & 57 & $<1$ & 34 & $<1$ & 22 & $<1$ & 24 & $<1$ & 21 \\
\hline 5 & Ileum & 25 & 79 & & & & & & & & \\
\hline 6 & Cecum & 96 & 86 & $<1$ & 78 & & & & & & \\
\hline
\end{tabular}

* Each value is the mean of the samples collected during the 3 day interval. Remainder of ${ }^{3 i} S$ was predominantly taurine. Total fecal recovery in 8 days was 3,1 , and $1 \%$ of dose for subjects 1,2 , and 3 , respectively.

Accordingly, the fractional turnover rate permitted a direct estimate of the extent of deconjugation during enterohepatic cycling. Recent measurements suggest that the bile acid pool circulates about 4-8 times a day in health (17). For 6 cycles a day, about $7 \%$ of cholyltaurine was deconjugated per cycle. This value is less than half of that previously observed for cholylglycine (1). The lower deconjugation rate of cholyltaurine may be caused by greater resistance of cholyltaurine to bacterial deconjugation, as suggested by Aries and Hill (18) and Nair, Gordon, and Reback (19), or by more proximal absorption (decreased exposure to deconjugaing bacteria) or both.

Similar turnover rates of cholyl and taurine moieties. The lack of appreciable reincorporation into cholyltaurine of either the liberated cholyl moiety or the taurine moiety explains the similar turnover rates. The liberated

TABLE VII

${ }^{3}$ H from $\left[2,4-{ }^{3} \mathrm{H}\right]$ cholyltaurine Entering Body. Water

\begin{tabular}{|c|c|c|c|c|}
\hline Subject & $\begin{array}{c}\text { Maximal } \\
\text { urinary } \\
\text { sp act }\end{array}$ & Weight & $\begin{array}{l}\text { Body } \\
\text { water* }\end{array}$ & $\begin{array}{l}\text { Dose in } \\
\text { body } \\
\text { water }\end{array}$ \\
\hline & $d p m / m l \quad H_{2} O$ & $\mathrm{~kg}$ & lilers & $\%$ \\
\hline $\mathrm{C}^{\prime} \mathrm{T}_{1}$ & 101 & 80 & 48 & 22 \\
\hline $\mathrm{CT}_{2}$ & 98 & 100 & 60 & 27 \\
\hline $\mathrm{CT}_{3}$ & 124 & 66 & 40 & 23 \\
\hline $\mathrm{CT}_{4}$ & 97 & 68 & 41 & 18 \\
\hline $\mathrm{CT}_{5}$ & 133 & 75 & 45 & 27 \\
\hline $\mathrm{CT}_{6}$ & 191 & 60 & 36 & 31 \\
\hline $\mathrm{CT}_{7}$ & 130 & 107 & 64 & 38 \\
\hline $\mathrm{CT}_{8}$ & 152 & 100 & 60 & 40 \\
\hline Mean & 128 & 82 & 49 & 28 \\
\hline $\mathrm{SE}$ & 11 & 6 & 4 & 3 \\
\hline
\end{tabular}

* Calculated as 0.6 times body weight (16). cholyl moiety is in part absorbed as such. That which is not absorbed is largely 7-dehydroxylated to deoxycholic acid of which less than half is reabsorbed (2). The absorbed cholyl and deoxycholyl moieties are conjugated predominantly with glycine and, accordingly, little reincorporation into cholyltaurine or deoxycholyltaurine was observed. Similar observations have been made by Garbutt et al. (4).

The ratio of glycine-conjugated bile acids to taurineconjugated bile acid in bile is about 3 , but since there is less deconjugation of taurine-conjugated bile acids during enterohepatic cycling, the ratio of rates of conjugation is probably considerably greater than 3 even in health. For cholylglycine, about $3 \mathrm{mmol}$ is used daily for conjugation (1) ; for cholyltaurine, it is about $0.4 \mathrm{mmol}$ (Table I). Thus, the ratio of conjugation rates is about 8 , and about $10-15 \%$ of the cholyl moiety should have been reincorporated into cholyltaurine. Feeding of taurine is thought to increase the taurine pool, increase conjugation of bile acids with taurine $(20,21)$, and, as shown in these studies, enlarge the cholyltaurine pool. Under these conditions, greater reincorporation of the cholyl moiety into cholyltaurine should occur, evidenced by slower turnover rate of the cholyl moiety relative to taurine.

The low degree of incorporation, into cholyltaurine, of radioactivity from intravenously administered $\left[{ }^{85} \mathrm{~S}\right]$ taurine resulted from rapid dilution by large endogenous pools. Similar dilution is assumed to have occurred when taurine was given orally, since taurine is well absorbed when ingested by mouth (22). Thus, even if all liberated taurine had been absorbed as such, little reincorporation of liberated radioactivity would have been observed. However, in the 3 days after administration of cholyl $\left.{ }^{88} \mathrm{~S}\right]$ taurine, most of the urinary radioactivity was present in sulfate. After the administration of $\left[{ }^{*} \mathrm{~S}\right]$ - 
taurine by instillation into the distal small intestine or into the cecum but not by a parenteral route, urinary radioactivity was similarly found predominantly in sulfate. These observations suggest that taurine liberated by bacterial deconjugation of cholyltaurine may be oxidized to sulfate by intestinal bacteria, as was suggested by Schmidt, von Adelung, and Watson (22) and by White, Lewis, and White (23). Sulfate, which is known to be actively transported by the mouse ileum (24), was apparently absorbed together with a variable amount of free taurine that escaped bacterial cleavage of the C-S bond. The sulfate enters the body's sulfate pool from which it is excreted as such or converted to a variety of forms of organic sulfate (25-27). It seems unlikely that $\left[{ }^{35} \mathrm{~S}\right]$ taurine, observed in urine after cholyl $\left[{ }^{35} \mathrm{~S}\right]$ tattrine was given, was newly synthesized from absorbed $\left[{ }^{35} \mathrm{~S}\right]$ sulfate since taurine was the only nonsulfate compound in the urine that was labeled with ${ }^{35} \mathrm{~S}$. The ligh correlation between the fractional turnover rate of tatrine and the percentage of administered ${ }^{35} \mathrm{~S}$ recovered in the urine in the first $24 \mathrm{~h}$ is thus dependent on bacterial conversion of liberated free taurine to sulfate which, in turn, is absorbed and in part rapidly excreted.

The absence of ${ }^{35} \mathrm{~S}$ in the taurine-conjugated dihydroxy bile acid fraction indicates that, in these subjects, no detectable dehydroxylation without deconjugation occurred. Cholylglycine has been shown to be dehydroxylated without deconjugation both in vitro and in vivo in some instances (1).

Fate of cholyl label. Body water became rapidly labeled with ${ }^{8} \mathrm{H}$. We suspect that ${ }^{3} \mathrm{H}$ release was related to bacterial desaturation (15) of 3-keto bile acids which have been detected in the feces (28). Furthermore, at the $\mathrm{pH}$ of the colonic lumen, ${ }^{8} \mathrm{H}$ in positions 2 and 4 of a 3-keto bile acid might exchange nonenzymatically with water, leading to excretion of ${ }^{3} \mathrm{H}$ in the urine. However, release of ${ }^{3} \mathrm{H}$ as $\left[{ }^{3} \mathrm{H}\right] \mathrm{H}_{2} \mathrm{O}$ followed by equilibration with body water would not materially affect the calculation of pool size and turnover rate, provided the bile acids involved had already been lost from the enterohepatic circulation. Indeed, the turnover rates of ${ }^{3} \mathrm{H}$-labeled bile acids reported previously by us $(1,2)$ agree well with those found by Vlahcevic, Miller, Farrar, and Swell (29) using ${ }^{14} \mathrm{C}$-labeled acids. Evidence that bile acid kinetics may be determined validly by using $2,4-^{3} \mathrm{H}$-labeled bile acids has previously been presented for two healthy subjects (5). However, additional confirmation of this thesis would now appear warranted.

Mctabolism of steroid and amino acid moietics of conjugated cholyl bile acids in man. The present study as well as that previously reported for cholylglycine (1) permit some general conclusions. For both conjugated trihydroxy bile acids, the majority of secreted bile acid is absorbed without deconjugation, although cholylgly- cine is hydrolyzed more than twice as rapidly as cholyltaurine. More than half of the liberated cholyl moiety is conserved and is reconjugated with glycine or taurine, the idea of deconjugation and reconjugation during enterohepatic cycling first being suggested by Norman (30) and subsequently by Heaton, Austad, Lack, and Tyor (31). Glycine conjugation usually predominates but, after taurine supplementation, taurine conjugation will increase so that the liberated cholyl moiety is now incorporated into the cholyltaurine pool. The glycine or taurine which is liberated is reabsorbed to some extent as such but enters large metabolic pools. The remaining glycine and taurine are degraded by bacteria to lower molecular weight substances which are well absorbed and also enter large metabolic pools; little fecal excretion of radioactivity from $\left[1{ }^{14} \mathrm{C}\right]$ glycine or $\left[{ }^{35} \mathrm{~S}\right]$ taurine occurs. For cholyl $\left[1-{ }^{14} \mathrm{C}\right]$ glycine the rate of deconjugation may be predicted with considerable accuracy by measurement of ${ }^{14} \mathrm{CO}_{2}$ excretion in breath and for cholyltaurine, by measurement of $\left[{ }^{35} \mathrm{~S}_{\mathrm{SO}_{4}}=\right.$ excretion in urine. Additional studies are required to define the fate of the nitrogen atom of both glycine and taurine, the methyl carbon of glycine, and both carbon atoms of taurine.

\section{ACKNOWLEDGMENTS}

We acknowledge the invaluable technical assistance of Miss Susan B. Coffin and Mr. Richard Tucker (Mayo Clinic), and Miss Judith Poje, Mr. Gerald Poje, and Mrs. Cynthia Sargente (Institute for Basic Research in Mental Retardation).

This investigation was supported in part by Research Grants AM-6908 and RR-585 from the National Institutes of Health, Public Health Service; and by grants from the Share Foundation, Mead Jolnnson Company, and New York State Department of Mental Hygiene.

\section{REFERENCES}

1. Hepner, G. W., A. F. Hofmann, and P. J. Thomas. 1972. Metabolism of steroid and amino acid moieties of conjugated bile acids in man. I. Cholylglycine. J. Clin. Invest. 51: 1889 .

2. Hepner, G. W., A. F. Hofmann, and P. J. Thomas. 1972. Metabolism of steroid and amino acid moieties of conjugated bile acids in man. II. Glycine-conjugated dihydroxy bile acids. J. Clin. Ini'est. 51: 1898.

3. Sjövall, J. 1960. Bile acids in man under normal and pathological conditions. Bile acids and steroids 73. Clin. Chim. Acta. 5: 33 .

4. Garbutt, J. T., R. M. Wilkins, L. Lack, and M. P. Tyor. 1970. Bacterial modification of taurocholate during enterohepatic recirculation in normal man and patients with small intestinal disease. Gastroenterology. 59: 553 .

5. Hofmann, A. F., P. A. Szczepanik, and P. D. Klein. 1968. Rapid preparation of tritium-labeled bile acids by enolic exchange on basic alumina containing tritiated water. J. Lipid Res. 9: 707.

6. Norman, A. 1955. Preparation of conjugated bile acids using mixed carboxylic acid anhydrides: bile acids and steroids 34. Ark Kemi. 8: 331. 
7. Snyder, F., and H. Kimble. 1965. An automatic zonal scraper and sample collector for radioassay of thinlayer chromatograms. Anal. Biochem. 11: 510.

8. Stempfel, R. S., Jr., and J. B. Sidbury, Jr. 1964. Studies with the hydroxysteroid dehydrogenases: I. A simplified method for the enzymatic estimation of 3- and 17hydroxysteroids. J. Clin. Endocrinol. Metab. 24: 367.

9. Lindstedt, S. 1957. The turnover of cholic acid in man. Bile acids and steroids 51. Acta Physiol. Scand. 40: 1.

10. Sturman, J. A., P: A. Cohen, and G. E. Gaull. 1969. Effects of vitamin $\mathrm{B}_{8}$ on transsulfuration. Biochem. Med. $3: 244$.

11. Sturman, J. A., and P. A. Cohen. 1971. Cystine metabolism in vitamin $B_{6}$ deficiency: evidence of multiple taurine pools. Biochem. Med. 5: 245.

12. Wainer, A., J. S. King, Jr., H. O. Goodman, and J. J. Thomas. 1966. ${ }^{85} \mathrm{~S}$ taurine metabolism in normal and mongoloid individuals. Proc. Soc. Exp. Biol. Med. $121: 212$.

13. Goodman, H. O., A. Wainer, J. S. King, Jr., and J. J. Thomas. 1967. ${ }^{\text {s5 }} \mathrm{S}$ 2-hydroxyethanesulfonic acid (isethionic acid) in urine of human subjects given ${ }^{35} \mathrm{~S}$ taurine. Proc. Soc. Exp. Biol. Med. 125: 109.

14. Sjövall, J. 1959. Dietary glycine and taurine on bile acid conjugation in man: bile acids and steroids 75 . Proc. Soc. Exp. Biol. Med. 100: 676.

15. Aries, V. C., P. Goddard, and M. J. Hill. 1971. Degradation of steroids by intestinal bacteria. III. 3-Oxo-5 $\beta$ steroid $\Delta^{1}$-dehydrogenase and 3-oxo-5 $\beta$-steroid $\Delta^{4}$-dehydrogenase. Biochim. Biophys. Acta. 248: 482.

16. Richmond, C. R., W. H. Langham, and T. T. Trujillo. 1962. Comparative metabolism of tritiated water by mammals. J. Cell. Comp. Physiol. 59: 45.

17. Brunner, H., A. F. Hofmann, and W. H. J. Summerskill. 1972. Daily secretion of bile acids and cholesterol measured in health. Gastroenterology. 62: 188. (Abstr.)

18. Aries, V., and M. J. Hill. 1970. Degradation of steroids by intestinal bacteria. I. Deconjugation of bile salts. Biochim. Biophys. Acta. 202: 526.

19. Nair, P. P., M. Gordon, and J. Reback. 1967. The enzymatic cleavage of the carbon-nitrogen bond in $3 \alpha, 7 \alpha$, $12 \alpha$-trihydroxy-5 $\beta$-cholan-24-oylglycine. J. Biol. Chem. 242: 7 .
20. Sjövall, J. 1959. Dietary glycine and taurine on bile acid conjugation in man. Bile acids and steroids 75 . Proc. Soc. Exp. Biol. Med. 100: 676.

21. Garbutt, J. T., K. W. Heaton, L. Lack, and M. P. Tyor. 1969. Increased ratio of glycine- to taurine-conjugated bile salts in patients with ileal disorders. Gastroenterology. $56: 711$.

22. Schmidt, C. L. A., E. von Adelung, and T. Watson. 1918. On the elimination of taurin administered to man. J. Biol. Chem. 33: 501.

23. White, F. R., H. B. Lewis, and J. White. 1937. The metabolism of sulphur. XXIV. The metabolism of taurine, cysteic acid, cystine, and of some peptides containing these amino acids. J. Biol. Chem. 117: 663 .

24. Batt, E. R. 1969. Sulfate accumulation by mouse intestine: influence of age and other factors. Am. J. Phys iol. $217: 1101$.

25. Borsook, H., G. Keighley, D. M. Yost, and E. McMillan. 1937. The urinary excretion of ingested radioactive sulfur. Science (Wash. D. C.). 86: 525.

26. Dziewiatkowski, D. D. 1949. On the utilization of exogenous sulfate sulfur by the rat in the formation of ethereal sulfates as indicated by the use of sodium sulfate labeled with radioactive sulfur. J. Biol. Chem. 178: 389.

27. Dziewiatkowski, D. D. 1949. Rate of excretion of radioactive sulfur and its concentration in some tissues of the rat after intraperitoneal administration of labeled sodium sulfate. J. Biol. Chem. 178: 197.

28. Eneroth, P., B. Gordon, R. Ryhage, and J. Sjövall. 1966. Identification of mono- and dihydroxy bile acids in human feces by gas-liquid chromatography and mass spectrometry. J. Lipid Res. $7: 511$.

29. Vlahcevic, Z. R., J. R. Miller, J. T. Farrar, and L. Swell. 1971. Kinetics and pool size of primary bile acids in man. Gastroenterology. $61: 85$.

30. Norman, A. 1955. Metabolism of glycine-conjugated bile acids in the rat: bile acids and steroids 36 . Kungl. Fysiogr. Sallsk. I Lund Forhandl. 25: 1.

31. Heaton, K. W., W. I. Austad, L. Lack, and M. P. Tyor. 1968. Enterohepatic circulation of ${ }^{14} \mathrm{C}$-labeled bile salts in disorders of the distal small bowel. Gastroenterology. 55: 5 . 